\title{
DISKRIMINASI TERHADAP PENDIDIKAN ISLAM DI INDONESIA: Latar Belakang Muncul dan Upaya Menghilangkannya
}

\author{
Oleh: Anhar*
}

\begin{abstract}
Islamic education in Indonesia does not recognize dichotomy system despite the fact that, historically, the dichotomy between secular education and Islamic education in the colonial era did exist. It is claimed that the dichotomy between the two areas is more of a discriminative issue. One alternative solution to this is an integrated model, where centralized management of Islamic education by the Ministry of Religious Affairs and the secular education under the management of the ministry of the national education, to be handled by the local government. This is in accordance with the National Constitution no. 32, 2004 about local government.
\end{abstract}

KEYWORDS: Diskriminasi, pendidikan Islam, integrasi

DISKRIMINASI terhadap pendidikan Islam merupakan salah satu permasalahan dalam penyelenggaraan pendidikan di negeri ini. Pada awalnya, problem ini terjadi di Indonesia dalam bentuk dikotomi antara politik vs agama terutama dalam konteks pendidikan. Dikotomi yang demikian ini, pertama kali diprakarsai oleh Karel Frederick Holle dengan menolak secara tegas pengajaran agama Islam di sekolah-sekolah pemerintah bahkan menawarkan tulisan-tulisan yang berbeda dengan tulisan Arab, dan pengajaran agama diserahkan kepada pesantren-pesantren dan langgar-langgar. ${ }^{1}$

Dari perspektif historis, dikotomi di dunia Islam memang sudah terjadi sejak zaman kemunduran Islam (jatuhnya Baghdad dan Andalusia) hingga sekarang, sementara Islam menganggap ilmu pengetahuan sebagai sebuah konsep yang skematis dan holistis.

Agama, karena mengandung ajaran-ajaran absolut, sering dipandang statis dan tidak sejalan, kalau tidak bertentangan, dengan ilmu pengetahuan dan teknologi yang selalu mengalami dinamika. Dengan demikian, terjadi ketidakserasian antara agama dengan ilmu pengetahuan dan teknologi yang nantinya berpengaruh pada lembaga pendidikan sebagai produser sumber daya manusia.

*Kandidat Magister Pendidikan Islam pada Program Pascasarjana UIN Alauddin Makassar ini adalah guru Pendidikan Agama Islam di SMP Negeri 4 Jonggat, Kabupaten Lombok Tengah. 
Hal tersebut, antara lain terjadi karena jiwa manusia diwarnai oleh pemikiran modern yang kaya dengan rekayasa akal, tetapi lekang dari nuansa keagamaan. Demikian yang di maksud oleh Ismail Raji al-Faruqi sehingga muncul ide pemikirannya tentang Islamisasi ilmu pengetahuan sebagaimana dikutip Kafrawi Ridwan. ${ }^{2}$

Khulafä' al-Rāsyidīn yang dilanjutkan oleh beberapa daulah sesudahnya, telah menunjukkan keterkaitan antara pengetahuan agama dengan pengetahuan umum, sehingga banyak melahirkan cendekiawan muslim dalam berbagai bidang ilmu pengetahuan, seperti: al-Kindi, Ibn Sina, alFarabi, al-Khawarizmi, Ibn Khaitam, Ibn Maskawaih, dan lain-lain. Bahkan, jika membicarakan tentang kemajuan pendidikan Islam, maka akan merujuk pada abad-abad pertama perkembangan Islam hingga awal Abad Pertengahan.

Mehdi Nakoosten menulis bahwa kontribusi Islam terhadap teori dan praktik pendidikan Barat sangat banyak. Hal ini dapat dibuktikan dengan diterjemahkannya karya-karya cendekiawan Muslim tentang sains, filsafat, dan bidang lainnya ke dalam bahasa latin, sehingga memperkaya kurikulum Barat, khususnya di Eropa Barat Laut. Di samping itu, orangorang muslim telah memberi metode eksperimental kepada Barat, sekalipun masih kurang sempurna. ${ }^{3}$

Senada dengan pendapat tersebut, Ahmad M. Sewang menulis bahwa penguasaan iptek di dunia Barat sekarang, dipastikan sebagai lanjutan dan pengaruh dari kemajuan yang pernah dicapai umat Islam pada abad pertengahan. 4

Deskripsi tersebut menunjukkan bahwa pada masa awal munculnya Islam sampai abad pertengahan, umat Islam tidak mendikotomikan ilmu pengetahuan. Hal ini merupakan salah satu yang melatarbelakangi Islam mampu mengungguli peradaban Romawi dan Parsi yang lebih dulu eksis. ${ }^{5}$

Dalam perkembangannya, kemajuan tersebut tinggal kenangan yang tertulis dalam buku-buku sejarah, bahkan Islam sudah terbelakang dalam berbagai aspek, yang antara lain dilatarbelakangi oleh adanya dikotomi dan berimplikasi pada diskriminasi terhadap pendidikan Islam itu sendiri.

Diskriminasi terhadap pendidikan Islam, juga terjadi di Indonesia dengan latar belakang yang berbeda. Diskriminasi tersebut telah memporak-porandakan sistem pendidikan, karena lembaga pendidikan Islam sering dipandang sebagai lembaga pendidikan kelas dua, baik dari aspek kelembagaannya, personal, stakeholders, maupun output-nya.

Tulisan ini mengungkap diskriminasi terhadap pendidikan Islam dalam perspektif historis, yang meliputi: latar belakang munculnya diskriminasi terhadap pendidikan Islam di Indonesia, bentuk-bentuknya, dan 
alternatif yang sebaiknya ditempuh dalam menghilangkan diskriminasi tersebut.

\section{LATAR BELAKANG MUNCULNYA DISKRIMINASI TERHADAP PENDIDIKAN ISLAM DI INDONESIA}

Diskriminasi terhadap pendidikan Islam merupakan tantangan terhadap perkembangan ilmu pengetahuan di Indonesia yang mayoritas penduduknya beragama Islam.

Secara umum, diskriminasi terhadap pendidikan Islam sebagai akibat dari adanya dikotomi pendidikan Islam vs pendidikan umum. Dikotomi terhadap pendidikan Islam, timbul sebagai akibat dari beberapa hal. Pertama, perkembangan pembidangan ilmu pengetahuan yang demikian pesat, sehingga membentuk berbagai cabang disiplin ilmu, bahkan anak cabangnya. Kedua, pengaruh histori perkembangan umat Islam ketika mengalami kemunduran sejak Abad Pertengahan. Ketiga, internal kelembagaan pendidikan Islam yang kurang mampu melakukan pembenahan dan pembaruan. ${ }^{6}$

Ikhrom menulis bahwa dikotomi dalam sistem pendidikan di dunia muslim terjadi antara lain: 1) Sistem pendidikan Islam (tradisional) lebih cenderung ekslusif ketimbang inklusif; 2) Stagnasi pemikiran Islam. Umat Islam lebih cenderung mengagungkan kejayaan masa lalu tanpa berpikir cara mengembalikan kejayaan itu di masa sekarang; 3) Penjajahan Barat atas dunia Islam; dan 4) Modernisasi atas dunia Islam. Modernisasi muncul sebagai perpaduan antara dua ideologi Barat, Teknikisme dan Nasionalisme. Dan hal ini lebih berbahaya daripada tradisionalisme yang sempit. ${ }^{7}$

Masuknya Islam di Indonesia dibawa oleh para mubalig dari Arab 8 tanpa adanya diskriminasi. Diskriminasi terhadap pendidikan Islam di Indonesia muncul sejak zaman kolonial. Dalam perkembangannyasetelah mendapat kontak dari para perantau yang datang dari luar Arabajaran-ajaran yang dibawa oleh para mubalig itu mengalami akulturasi bahkan asimilasi dari bentuk aslinya, karena di Indonesia banyak perantau yang datang pada saat itu. Zuhairini, dkk., menulis bahwa Indonesia mudah dikenal oleh bangsa-bangsa di Timur Tengah dan Timur Jauh dipengaruhi oleh dua faktor utama, yaitu: 1) faktor geografisnya yang strategis, dan 2) faktor kesuburan tanahnya yang menghasilkan bahanbahan keperluan hidup yang dibutuhkan oleh bangsa-bangsa lain. ${ }^{9}$

Semakin lama para mubalig menyebarkan Islam di Indonesia, semakin luas penyebaran Islam di Nusantara ini, antara lain ke Pulau Jawa, Kalimantan, Maluku, dan Sulawesi, bahkan masuk ke Nusa Tenggara seperti Bima, Sumbawa, dan Lombok. 
Munculnya pendidikan Islam di Indonesia, seiring dengan masuknya Islam ke negeri ini, walaupun masih bersifat face to face, belum berbentuk lembaga. Dalam perkembangan selanjutnya, pendidikan Islam yang berlangsung secara pribadi tersebut, melembaga dalam bentuk mesjid yang akhirnya berkembang menjadi lembaga pendidikan Islam berbentuk pesantren.

Pada masa ini, pendidikan Islam di Indonesia ditekankan pada pemahaman terhadap ajaran Islam yang bersumber dari Alquran dan Hadis. Oleh karena itu, referensi yang digunakan dalam memahami ajaran Islam yang bersumber dari Alquran dan Hadis tersebut, diperoleh melalui pembacaan terhadap kitab-kitab klasik-yang lebih dikenal dengan kitab kuning - sehingga kemampuan memahami kitab-kitab klasik itu menjadi standar utama dalam mengukur tinggi rendahnya ilmu agama seseorang.

Dalam beberapa dekade berikutnya - setelah negeri ini dikenal oleh bangsa-bangsa Eropa-banyak orang-orang Eropa yang datang ke Indonesia yang akhirnya mampu menancapkan kekuasaannya di negeri ini sebagai penjajah, antara lain Belanda. Kedatangan Belanda ke Indonesia, bukan hanya menguasai perdagangan, akan tetapi, mereka juga membawa misionaris (untuk menyebarkan agamanya). Hal ini berimbas juga pada pendidikan Islam yang sudah ada pada waktu itu, yaitu pesantren. Pendidikan yang dibangun oleh kolonial Belanda mulai berdiri di Indonesia sekitar abad ke-17.

Pendidikan yang didirikan oleh kolonial Belanda ini, bersifat sekuler, dengan tidak mengajarkan ilmu agama di sekolah-sekolah pemerintah. Demikian juga halnya dengan lembaga pendidikan Islam pada waktu itu tidak mengajarkan ilmu-ilmu umum. ${ }^{10}$

Bahkan dalam perkembangan berikutnya, setelah Kolonial Belanda menguasai Nusantara secara permanen, lembaga-lembaga pendidikan Islam yang sudah ada, yang berbentuk pesantren tereliminasi dari kemajuan, sehingga lembaga pendidikan Islam yang sudah ada, harus mencari tempat berkembang yang lebih leluasa, yang jauh dari intimidasi kolonial Belanda yaitu di pedesaan. Dengan demikian, muncul sebuah paradigma baru terhadap lembaga pendidikan Islam, yaitu pendidikan Islam merupakan pendidikan yang terkucilkan, jauh dari perkembangan modern, dan hanya cocok untuk masyarakat pedesaan, sedangkan pendidikan yang datang dari Barat merupakan pendidikan yang dekat dengan kemajuan. Realitas seperti ini membentuk pola pendidikan di Indonesia sampai saat ini dalam wajah dikotomi.

Sebagai gambaran yang jelas tentang diskriminasi terhadap lembaga pendidikan Islam di Indonesia, Karel A. Steenbrink menulis bahwa pada 
tahun 1888, menteri Kolonial menolak memberikan subsidi kepada sekolah-sekolah Islam karena campur tangan Gubernur Jenderal yang tidak mau mengorbankan keuangan negara untuk sekolah-sekolah tersebut, yang pada akhirnya hanya berhasil mengembangkan suatu sistem pendidikan saja. Pada saat itu, usul untuk menggabungkan pendidikan Islam ditolak. ${ }^{11}$

Dengan demikian, jelaslah bahwa benih diskriminasi terhadap pendidikan Islam di Indonesia dimulai sejak adanya kebijakan yang diambil oleh Kolonial.

Setelah Indonesia merdeka, diskriminasi terhadap pendidikan Islam yang merupakan warisan kolonial Belanda tetap berlangsung, antara lain terlihat dalam Undang-Undang No. 4 Tahun 1950 tentang Dasar-dasar Pendidikan dan Pengajaran di Sekolah pasal 31 disebutkan bahwa warga negara diberikan kesempatan untuk mendirikan sekolah pertikelir. ${ }^{12}$

Di samping itu, terbit Peraturan Bersama Menteri Pendidikan, Pengajaran dan Kebudayaan dan Menteri Agama No. 17678/Kab. tanggal 16 Juli 1951 dan No. K/1/9180 tanggal 16 Juli 1951 tentang Perubahan Peraturan Bersama Menteri Pendidikan, Pengajaran dan Kebudayaan dan Menteri Agama No. 1432/Kab. tanggal 20 Januari 1951 dan No. K/1/651 tanggal 20 Januari 1951 menimbulkan kesan bahwa pendidikan agama masih dianaktirikan jika dibandingkan dengan pendidikan umum. ${ }^{13}$

Diskriminasi tersebut, terus berlanjut hingga ditetapkannya SKB 3 Menteri tahun 1975 tentang Peningkatan Mutu Pendidikan pada Madrasah. ${ }^{14}$ Lahirnya SKB 3 Menteri tersebut mengakui kesejajaran antara pendidikan umum dengan pendidikan Islam, dalam tataran status ijazah dan output-nya. Hal tersebut dapat dipahami bahwa diskriminasi masih terjadi dalam perspektif pengelolaan dan pembiayaan kedua jenis lembaga pendidikan tersebut.

Diskriminasi pendidikan yang terjadi di Indonesia, masih dirasakan sampai saat ini, terutama dalam praktik penyelenggaraan pendidikan itu sendiri, baik dari aspek pengelolaan, output, maupun personalnya. Di beberapa lembaga pendidikan Islam (khususnya madrasah swasta), banyak tenaga pendidiknya tidak memenuhi standar kompetensi, sehingga mempengaruhi output yang dihasilkan.

Di samping itu, menurut penulis, diskriminasi pendidikan di Indonesia ini dilatarbelakangi oleh pola pikir umat Islam di Indonesia sendiri. Dengan latar belakang pemahaman terhadap ajaran Islamberpijak pada pemahaman Islam berdasarkan fikih Imam Syafi'i, teologi Asy'ariyah yang lebih condong ke paham Jabariyah-maka umat Islam di Indonesia berpikiran sempit dalam memahami Islam. 
Bahkan berbekal sebuah pemahaman yang sempit, umat Islam Indonesia sering memberikan justifikasi kebenaran dengan tidak mempertimbangkan aspek sosiologis, historis, antropologis, psikologis, dan sebagainya, hanya memahami sesuatu dari aspek teologis saja, sehingga setiap kemajuan yang ditemukan oleh orang-orang Barat dihubungkan dengan ajaran Islam - menurut pemahamannya sendiri. Dengan demikian, terjadi apriori terhadap kemajuan pemikiran Barat dan lebih memilih terkungkung dalam pemahamannya yang sempit.

Dari pemaparan di atas, maka faktor internal umat Islam di Indonesia turut mempengaruhi munculnya diskriminasi terhadap pendidikan Islam di Indonesia sampai saat ini.

\section{BENTUK-BENTUK DISKRIMINASI TERHADAP PENDIDIKAN ISLAM DI INDONESIA}

Jika ditelaah lebih jauh latar belakang munculnya diskriminasi terhadap pendidikan Islam di Indonesia di atas, maka secara garis besar bentuk diskriminasi tersebut dapat dilihat dari dua sisi, yaitu: pertama, sisi das sein (realitas) dan das sollen (idealitas), dan kedua, sisi epistemologis.

\section{Sisi Das Sein (Realitas) dan Das Sollen (Idealitas)}

Merujuk kepada Undang-undang RI No. 20 Tahun 2003 tentang Sistem Pendidikan Nasional, dan PP No. 55 Tahun 2007 tentang Pendidikan Agama dan Pendidikan Keagamaan, maka semestinya diskriminasi terhadap pendidikan agama (baca: Islam) tidak terjadi lagi. Dalam praktik penyelenggaraan pendidikan di Indonesia, secara global tetap terjadi diskriminasi terhadap pendidikan Islam.

Menurut Undang-undang Nomor 32 Tahun 2004 tentang Pemerintahan Daerah, dan Undang-undang Nomor 33 Tahun 2004 tentang Perimbangan Keuangan antara Pemerintah Pusat dan Pemerintah Daerah, maka pendidikan diselenggarakan oleh pemerintah daerah. ${ }^{15}$ Akan tetapi, dalam praktik penyelenggaran pendidikan di Indonesia sampai saat ini, lembaga pendidikan agama masih bernaung di departemen yang sentralistis.

Lembaga pendidikan Islam (baca: Madrasah) masih bernaung di bawah Departemen Agama, sedangkan Departemen Agama itu sendiri masih sentralistis. Lembaga pendidikan umum dikelola oleh pemerintah daerah yang desentralistis. Realitas yang demikian ini, menunjukkan bahwa diskriminasi terhadap pendidikan Islam di Indonesia masih terjadi, sehingga prinsip otonomi bagi sekolah dalam mengatur strategi pengembangan sekolah masing-masing masih perlu dipertanyakan. 
Sebagai implikasi dari penyelenggaraan pendidikan di Indonesia dengan sistem ganda seagaimana penulis paparkan di atas, maka terjadi diferensiasi yang terjal antara lembaga pendidikan agama (madrasah) dengan lembaga pendidikan umum. Dalam tataran teori, kedua bentuk penyelenggaraan pendidikan itu disejajarkan tanpa diskriminasi, tetapi dalam praktik, diskriminasi masih saja terjadi.

Di samping itu, sebagai dampak dari adanya penyelenggaraan pendidikan dengan sistem ganda ini adalah sistem sertifikasi tenaga pendidik. Sampai saat tulisan ini muncul, tunjangan profesional Guru Besar di lingkungan Departemen Agama belum dibayar, sedangkan tunjangan profesional Guru Besar di lingkungan Departemen Pendidikan Nasional sudah dibayar.

Akibat lain yang ditimbulkan dari diskriminasi ini adalah sertifikasi guru-guru pendidikan agama Islam di Propinsi Nusa Tenggara Barat, sampai saat ini belum jelas nasibnya. Sertifikasi guru mata pelajaran umum dilakukan oleh Depdiknas, akan tetapi sertifikasi guru pendidikan agama Islam dilakukan oleh Depag, yang tentu saja hasil dan penanganannya berbeda pula.

Semestinya, jika merujuk ke Undang-undang RI No. 20 Tahun 2003 tentang Sistem Pendidikan Nasional tidak akan ada diskriminasi terhadap lembaga pendidikan Islam, karena baik pendidikan umum maupun pendidikan agama Islam sama-sama mencerdaskan bangsa.

Realitas yang demikianlah, menurut penulis merupakan kesenjangan antara das sein dengan das sollen.

\section{Sisi Epistemologis}

Diskriminasi terhadap pendidikan Islam di Indonesia juga terjadi dari perspektif epistemologi.

Penyebutan terhadap pendidikan Islam dan pendidikan umum yang berbeda membawa konsekuensi imaj yang berbeda pula. Jika seseorang yang merupakan output lembaga pendidikan umum, apalagi SMK, akan lebih diakui kompetensinya di masyarakat jika dibandingkan dengan output pesantren yang dianggap hanya bisa ilmu agama. Hal ini merupakan tendensi yang miring terhadap lembaga pendidikan Islam.

Menurut hemat penulis, yang demikian itu terjadi sebagai pengaruh dari performance yang ditampilkan di tengah masyarakat oleh output lembaga pendidikan Islam yang berorientasi pada dosa dan pahala, surga dan neraka, yang akhirnya menjadikan masyarakat fatalistik (jabariyah). Dan merupakan refleksi pemahaman masyarakat terhadap Islam dengan pendekatan sufistik. Pemahaman terhadap Islam dengan pendekatan 
rasional yang bercorak liberal mereka anggap sebagai sebuah perlawanan dan pemahaman terhadap ayat-ayat Allah yang menggunakan hawa nafsu dan hal ini dinilai sebagai sebuah dosa besar.

Dari perspektif epistemologi, sebenarnya ilmu pengetahuan berasal dari Allah, manusia tidak dapat menciptakan ilmu pengetahuan. Manusia hanya bisa menemukan ilmu yang telah diciptakan Allah. Dengan demikian, maka perkembangan ilmu pengetahuan itu berkembang setiap saat. Umar A. Jenie menggambarkan tahapan perkembangan aplikasi industrialisasi Newtonian: pertama, mekanisasi pada abad ke-17; kedua, energisasi pada abad ke-18; ketiga, optimalisasi pada abad ke-18-19; dan keempat, otomatisasi pada abad ke-19 dan 20.16

\section{UPAYA-UPAYA DALAM MENGHILANGKAN DISKRIMINASI TERHADAP PENDIDIKAN ISLAM DI INDONESIA}

Diskriminasi terhadap Pendidikan Islam di Indonesia, sampai sekarang masih terasa, terutama dalam tataran praksis. Banyak pakar yang telah memberikan alternatif yang mesti ditempuh dalam rangka menghilangkan diskriminasi terhadap pendidikan Islam di Indonesia.

Sebagaimana penulis paparkan di atas, bahwa diskriminasi merupakan akibat dari adanya dikotomi. Oleh karena itu, untuk menghilangkan diskriminasi tersebut, dikotomi sebagai tunas munculnya perlu dihilangkan terlebih dahulu. Dalam menghilangkan dikotomi di dunia Islam, Ziauddin Sardar memberikan solusi menghilangkan sistem pendidikan dikotomis sebagaimana dikutip Ikhrom, pertama, dari segi epistemologi, umat Islam harus berani mengembangkan kerangka pengetahuan masa kini yang terartikulasi sepenuhnya. Kerangka pengetahuan yang dikembangkan dapat membantu mengatasi masalah-masalah moral dan etika; kedua, perlu ada gaya-gaya dan metode-metode aktivitas ilmiah dan teknologi yang sesuai tinjauan dunia, tetapi islami; ketiga, perlu ada teori sistem pendidikan yang memadukan ciri-ciri terbaik sistem tradisional dan sistem modern (integralistik). ${ }^{17}$

Di samping itu, Shodiq Abdullah mengajukan solusi mengatasi dikotomi ilmu dalam pendidikan Islam adalah dengan rekonsiliasi epistemologi agar rumusan sistem pendidikan Islam lebih fungsional dan marketable di masa depan.18 Jika hal ini tidak dilakukan, maka sistem pendidikan Islam tidak akan mampu menghadapi perubahan dan menjadi counter ideas terhadap globalisasi kebudayaan. ${ }^{19}$ Hal lain yang dilakukan dalam menghilangkan dikotomi terhadap pendidikan Islam adalah dengan mengintegrasikan antara ilmu agama dengan ilmu umum dengan mengislamkan atau melakukan purifikasi (penyucian) terhadap ilmu 
pengetahuan produk Barat, sehingga diperoleh ilmu pengetahuan yang islami. ${ }^{20}$

Selanjutnya, diskriminasi terhadap pendidikan Islam di Indonesia yang selama ini terjadi, tidak cukup dengan pengintegrasian ilmu umum dan ilmu agama dalam bentuk islamisasi pengetahuan. Akan tetapi diperlukan langkah yang lebih aplikatif, yang mencakup islamisasi secara holistis. Ide tersebut dikemukakan oleh A. Malik Fadjar dengan menekankan perlunya pengembangan pendidikan agama di perguruan tinggi umum. ${ }^{21}$

Langkah berikutnya yang ditempuh dalam menghilangkan dikotomi terhadap pendidikan Islam di Indonesia adalah dengan merubah status institusi perguruan tinggi Islam dari IAIN menjadi UIN. Hal ini sangat dimungkinkan, karena IAIN hanya konsen pada ilmu agama. Dengan Perubahan status IAIN menjadi UIN dimungkinkan adanya integrasi ilmu umum dengan ilmu agama secara komprehensif. Fakta yang demikian itu tampak jelas dengan institusi perguruan tinggi Islam sekarang ini yang telah muncul dalam bentuk universitas, antara lain: UIN Syahid Jakarta, UIN Sunan Kalijaga Yogyakarta, UIN Malang, UIN Sunan Ampel Surabaya, UIN Alauddin Makassar.

Dengan perubahan status IAIN menjadi UIN, masih muncul tanda tanya besar mengenai efektifitas upaya pengintegrasian ilmu umum dengan ilmu agama. Pengintegrasian kedua ilmu tersebut, ternyata tidak cukup dengan perubahan status saja, tetapi terdapat langkah yang lebih realistis yaitu dengan dielaborasinya materi perkuliahan umum dengan materi keagamaan.

Menurut hemat penulis, langkah tersebut mengandung nilai positif yang sangat banyak, dengan harapan nantinya dapat menghasilkan output berupa intelektual yang islami. Bahkan beberapa bulan yang lalu, pemerintah telah mencanangkan Badan Hukum Pendidikan (BHP). Akan tetapi masih terdapat kendala yang bersifat kompleks yaitu faktor pembiayaan dan pengelolaan yang masih ragu dan rancu.

Oleh karena itu, dalam rangka menghilangkan diskriminasi terhadap pendidikan Islam yang selama ini terjadi baik dari tingkat dasar, tingkat menengah, maupun tingkat tinggi, penulis lebih sependapat dengan rumusan langkah alternatif yang diajukan oleh Forum Kajian Pendidikan Departemen Agama sebagaimana dikutip Azyumardi Azra dari Fadhal AR Bafadhal, yaitu: pertama, eksistensi suprastruktur Ditjen Binbaga Depag tetap dipertahankan, sedangkan penyelenggaraan pendidikan dilimpahkan kepada Pemda Tingkat II; kedua, institusi Ditjen Binbaga Depag diintegrasikan ke dalam Depdiknas, dan penyelenggaraan pendidikan agama dan 
keagamaan diserahkan kepada Pemda sesuai dengan UU RI Nomor 22 Tahun 1999.22

Untuk lebih realistisnya, dalam rangka menghilangkan diskriminasi terhadap pendidikan Islam di Indonesia ini, hendaknya dilakukan integrasi penuh Ditjen Binbaga Depag ke dalam Depdiknas, sebagaimana alternatif kedua yang diajukan forum kajian Depag di atas. Dasar pertimbangan altenatif ini adalah Depag tetap eksis, tetapi tidak lagi mengelola pendidikan. Depag hanya mengelola urusan umat beragama. Sedangkan urusan pendidikan sepenuhnya diserahkan ke pihak Depdiknas. Hal ini lebih memungkinkan dihilangkannya diskriminasi terhadap pendidikan Islam di Indonesia, karena semua lembaga pendidikan dikelola oleh satu departemen yaitu Departemen Pendidikan Nasional.

Dengan demikian, pengelolaan lembaga pendidikan baik dari segi pengadaan tenaga pendidik, pembiayaan, maupun pengawasannya, akan lebih mudah dilaksanakan karena hanya ada satu kebijakan pengelolaan. Pengelolaan pendidikan oleh dua departemen seperti sekarang, sering menyebabkan terjadinya dualisme kebijakan yang dapat berimbas pada pelaksanaan kebijakan tersebut oleh lembaga pendidikan itu sendiri. Dengan pengintegrasian pengelolaan lembaga pendidikan dalam satu departemen, maka satu kebijakan berlaku untuk semua lembaga pendidikan baik lembaga pendidikan agama maupun lembaga pendidikan umum.

Hal tersebut lebih memungkinkan juga bagi masing-masing lembaga pendidikan untuk dapat melakukan pengembangan diri sehingga konsekuensi dari otonomi daerah (yang dalam pendidikan dikenal dengan istilah MBS=Manajemen Berbasis Sekolah) dapat dilaksanakan secara utuh.

Alternatif ini, memang dapat menimbulkan kekhawatiran kurangnya perhatian Depdiknas terhadap lembaga pendidikan Islam. Akan tetapi kekhawatiran tersebut semestinya tidak perlu ada, karena selama ini, Depdiknas tidak menganaktirikan lembaga pendidikan Islam yang berafiliasi dengannya.

Realitas seperti ini, di Sulawesi Selatan telah dibuktikan oleh Pesantren IMMIM yang berafiliasi ke Depdiknas. Hingga saat ini, pesantren tersebut tetap eksis dengan mutu yang tetap terpelihara tanpa meninggalkan eksistensi kepesantrenannya.23 Oleh karena itu, kekhawatiran terhadap kurangnya perhatian Depdiknas terhadap lembaga pendidikan Islam - apabila diintegrasikan secara penuh - tidak perlu ada.

\section{PENUTUP}

Diskriminasi terhadap pendidikan Islam di Indonesia dipengaruhi paling tidak oleh dua hal, yaitu: pertama, dalam perspektif sejarah, merupa- 
kan warisan penjajah Belanda yang mendiskriminasikan pendidikan Islam; kedua, faktor intern umat Islam yang kualitas sumber daya manusianya rendah dan dipengaruhi oleh paham fatalistik, sehingga kurang mampu memahami ayat-ayat Allah dan akhirnya berimbas pada kemunduran umat Islam tanpa mampu meraih kembali masa keemasan Islam yang telah dicapai umat Islam pada abad pertengahan.

Secara garis besar, diskriminasi terhadap pendidikan Islam di Indonesia, terdapat dua bentuk, yaitu: pertama, perbedaan das sein dan das sollen. Menurut undang-undang, seharusnya satuan pendidikan keagamaan Islam itu desentralistik, tetapi dalam praktiknya masih sentralistik yang berafiliasi pada Departemen Agama; kedua, Perbedaan epistemologi, adanya perbedaan-sumber ilmu pengetahuan-membawa konsekuensi perbedaan penempatan imaj terhadap satuan pendidikan umum dengan satuan pendidikan agama di tengah masyarakat.

Alternatif yang sebaiknya dilakukan dalam rangka menghilangkan dikotomi terhadap pendidikan Islam adalah mengintegrasikan satuan pendidikan kagamaan ke Depdiknas. Semua penyelenggaraan pendidikan hanya dilakukan oleh satu departemen yaitu Departemen Pendidikan Nasioanal, sedangkan Depag hanya menangani urusan yang berkaitan dengan keberagamaan umat. Dengan demikian, pengelolaan terhadap satuan pendidikan dapat dimaksimalkan.

\section{CATATAN AKHIR:}

1. Karel A. Steenbrink, Kawan dalam Pertikaian Kaum Kolonial Belanda dan Islam di Indonesia (1596-1942), Cet. I; Bandung: Mizan, 1995, h. 117-118.

2. Kafrawi Ridwan, et al., Ensiklopedi Islam Jld. 1, Jakarta: Ichtiar Baru Van Hoeve, 2001, h. 335.

3. Mehdi Nakosteen, Kontribusi Islam atas Dunia Intelektual Barat: Deskripsi Analisis Abad Keemasan Islam, terjemahan oleh Joko S. Kahar dan Supriyanto Abdullah, Surabaya: Risalah Gusti, 2003, h. 85.

4. Ahmad M. Sewang, "Kontribusi Peradaban Islam Terhadap Dunia Barat", Zaitun 3, no. 3 (Juli 2008), h. 2.

5. Lihat Nasir Baki, Arah Studi Keislaman di Indonesia, Pidato Pengukuhan Guru Besar Ilmu Metodologi Studi Islam dalam Rapat Senat Terbuka Luar Biasa UIN Alauddin Makassar, selasa 3 Juni 2008, h. 9-10.

6. Abd. Rahman Assegaf, "Pengantar", dalam Jasa Ungguh Muliawan, Pendidikan Islam Integratif: Upaya Mengintegrasikan Kembali Dikotomi Ilmu dan Pendidikan Islam, Yogyakarta: Pustaka Pelajar, 2005, h. viii-ix.

7. Lihat Ikhrom, "Dikhotomi Sistem Pendidikan Islam: Upaya Mengungkap Sebab-sebab dan Penyelesaiannya", dalam Ismail SM, et.al., Paradigma Pendidikan Islam, Yogyakarta: Pustaka Pelajar, 2001, h. 82-85.

8. Sebagian sejarawan berpendapat bahwa masuknya Islam di Indonesia, dibawa 
oleh pedagang dari Gujarat (India) dan ada yang berpendapat dari Iran, akan tetapi penulis berpendapat bahwa Islam masuk ke Indonesia dibawa oleh para mubalig yang memiliki mata pencaharian sebagai pedagang. Dengan demikian, menyebarkan Islam menjadi tujuan utama, sedangkan berdagang sebagai kegiatan untuk membiayai pemenuhan kebutuhan sehari-hari selama dalam berdakwah. Sedangkan mubalig yang membawa Islam ke Indonesia, penulis sepakat dengan pendapat sejarawan yang menyatakan bahwa Islam masuk ke Nusantara ini dibawa oleh mubalig dari Arab. Lihat Zuhairini, et.al., Sejarah Pendidikan Islam, Jakarta: Bumi Aksara, 2006, h. 133.

9. Zuhairini, et.al., Sejarah Pendidikan Islam, h. 130.

10. Lihat Haidar Putra Daulay, Sejarah Pertumbuhan dan Pembaruan Pendidikan Islam di Indonesia, Jakarta: Kencana, 2007, h. 1-2.

11. Karel A. Steenbrink, Pesantren Madrasah Sekolah: Pendidikan Islam dalam Kurun Moderen, Cetakan Pertama; Jakarta: LP3ES, 1986, h. 6-7.

12. Lihat Republik Indonesia, Undang-Undang No. 4 Tahun 1950 tentang Dasar-dasar Pendidikan dan Pengajaran di Sekolah, pasal 13, t.d.

13. Lihat Republik Indonesia, Peraturan Bersama Menteri Pendidikan, Pengajaran dan Kebudayaan dan Menteri Agama No. 17678/Kab. Tanggal 16 Juli 1951 dan No. K/1/9180 tanggal 16 Juli 1951 tentang Perubahan Peraturan Bersama Menteri Pendidikan, Pengajaran dan Kebudayaan dan Menteri Agama No. 1432/Kab. Tanggal 20 Januari 1951 dan No. K/1/651 tanggal 20 Januari 1951, t.d.

14. Lihat SKB 3 Menteri (Menteri Agama, Menteri Pendidikan dan Kebudayaan, serta Menteri Dalam Negeri) Tahun 1975. tentang Peningkatan Mutu Pendidikan pada Madrasah, t.d.

15. Lihat Republik Indonesia, Undang-Undang No. 32 Tahun 2004 tentang Pemerintahan Daerah dan No. 33 Tahun 2004 tentang Perimbangan Keuangan Antara Pemerintah Pusat dan Pemerintah Daerah, Bandung: Citra Umbara, 2008.

16. Umar A. Jenie "Paradigma dan Religiositas Perkembangan IPTEK" dalam Abdul Munir Mulkhan, et. al., Religiusitas Iptek, Yogyakarta: Pustaka Pelajar, 1988, h. 4-5.

17. Ikhrom, "Dikhotomi Sistem Pendidikan Islam: Upaya Mengungkap Sebabsebab dan Penyelesaiannya", dalam Ismail SM, et.al., Paradigma Pendidikan Islam, h. 91.

18. Shodiq Abdullah, "Rekonsiliasi Epistemologi: Ikhtiar Mengatasi Dikhotomi Ilmu dalam Pendidikan Islam", dalam Ismail SM, et.al., Paradigma Pendidikan Islam, Yogyakarta: Pustaka Pelajar, 2001, h. 103.

19. M. Zainuddin, Paradigma Pendidikan Terpadu: Menyiapkan Generasi Ulul Albab, Malang: UIN Malang Press, 2008, h. 82.

20. Abuddin Nata, et. al., Integrasi Ilmu Agama \& Ilmu Umum, Jakarta: RajaGrafindo Persada, 2005, h. 154.

21. Lihat A. Malik Fadjar, Visi Pembaruan Pendidikan Islam, Jakarta Pusat: Lembaga Pengembangan Pendidikan dan Penyusunan Naskah Indonesia (LP3NI), 1998, h. $145-148$.

22. Azyumardi Azra, Paradigma Baru Pendidikan Nasional: Rekonstruksi dan Demokratisasi, Jakarta: Penerbit Buku Kompas, 2002, h. 10-11.

23. Selengkapnya Lihat Muljono Damopolii, Pembaruan Pendidikan Islam di Makassar: Studi Kasus Pesantren Modern Pendidikan Al-Qur'an IMMIM 
Tamalanrea Makassar, Disertasi, Jakarta: Universitas Islam Negeri (UIN) Syarif Hidayatullah, 2006.

\section{DAFTAR PUSTAKA:}

Assegaf, Abd. Rahman, "Pengantar", dalam Jasa Ungguh Muliawan, Pendidikan Islam Integratif: Upaya Mengintegrasikan Kembali Dikotomi Ilmu dan Pendidikan Islam, Yogyakarta: Pustaka Pelajar, 2005.

Azra, Azyumardi, Paradigma Baru Pendidikan Nasional: Rekonstruksi dan Demokratisasi, Jakarta: Penerbit Buku Kompas, 2002.

Baki, Nasir, Arah Studi Keislaman di Indonesia, Pidato Pengukuhan Guru Besar Ilmu Metodologi Studi Islam dalam Rapat Senat Terbuka Luar Biasa UIN Alauddin Makassar, selasa 3 Juni 2008.

Damopolii, Muljono, Pembaruan Pendidikan Islam di Makassar: Studi Kasus Pesantren Modern Pendidikan Al-Qur'an IMMIM Tamalanrea Makassar, Disertasi, Jakarta: Universitas Islam Negeri (UIN) Syarif Hidayatullah, 2006.

Daulay, Haidar Putra, Sejarah Pertumbuhan dan Pembaruan Pendidikan Islam di Indonesia, Jakarta: Kencana, 2007.

Fadjar, A. Malik, Visi Pembaruan Pendidikan Islam, Jakarta Pusat: Lembaga Pengembangan Pendidikan dan Penyusunan Naskah Indonesia (LP3NI), 1998.

Ikhrom, "Dikhotomi Sistem Pendidikan Islam: Upaya Mengungkap Sebab-sebab dan Penyelesaiannya", dalam Ismail SM, et.al., Paradigma Pendidikan Islam, Yogyakarta: Pustaka Pelajar, 2001.

Jenie, Umar A., "Paradigma dan Religiositas Perkembangan IPTEK" dalam Abdul Munir Mulkhan, et. al., Religiusitas Iptek, Yogyakarta: Pustaka Pelajar, 1988.

Nakosteen, Mehdi Kontribusi Islam atas Dunia Intelektual Barat: Deskripsi Analisis Abad Keemasan Islam, terjemahan oleh Joko S. Kahar dan Supriyanto Abdullah, Surabaya: Risalah Gusti, 2003.

Nata, Abuddin, et. al., Integrasi Ilmu Agama \& Ilmu Umum, Jakarta: RajaGrafindo Persada, 2005.

Republik Indonesia, Undang-Undang RI Nomor 4 Tahun 1950 tentang Dasar-dasar Pendidikan dan Pengajaran di Sekolah, t.d.

------, Peraturan Bersama Menteri Pendidikan, Pengajaran dan Kebudayaan dan Menteri Agama No. 117678/Kab. Tgl 16 Juli 1951 dan No. K/1/9180 tanggal 16 Juli 1951 tentang Perubahan Peraturan Bersama Menteri Pendidikan, Pengajaran dan Kebudayaan dan Menteri Agama No. 1432/Kab. Tanggal 20 Januari 1951 dan No. K/1/651 tanggal 20 Januari 1951, t.d.

-------, Undang-Undang No. 32 Tahun 2004 tentangPemerintahan Daerah dan No. 33 Tahun 2004 tentang Perimbangan Keuangan Antara Pemerintah Pusat dan Pemerintah Daerah, Bandung: Citra Umbara, 2008.

Ridwan, Kafrawi, et al., Ensiklopedi Islam, Jilid 1, Jakarta: Ichtiar Baru Van Hoeve, 2001.

Sewang, Ahmad M., "Kontribusi Peradaban Islam Terhadap Dunia Barat", Zaitun 3, no. 3 (Juli 2008). 
Shodiq Abdullah, "Rekonsiliasi Epistemologi: Ikhtiar Mengatasi Dikhotomi Ilmu dalam Pendidikan Islam", dalam Ismail SM, et. al., Paradigma Pendidikan Islam, Yogyakarta: Pustaka Pelajar, 2001.

SKB 3 Menteri (Menteri Agama, Menteri Pendidikan dan Kebudayaan, serta Menteri Dalam Negeri) Tahun 1975. tentang Peningkatan Mutu Pendidikan pada Madrasah, t.d.

Steenbrink, Karel A., Pesantren Madrasah Sekolah: Pendidikan Islam dalam Kurun Moderen, Cetakan Pertama; Jakarta: LP3ES, 1986.

------, Kawan dalam Pertikaian Kaum Kolonial Belanda dan Islam di Indonesia (15961942), Cet. I; Bandung: Mizan, 1995.

Zainuddin, M., Paradigma Pendidikan Terpadu: Menyiapkan Generasi Ulul Albab, Malang: UIN Malang Press, 2008.

Zuhairini, et.al., Sejarah Pendidikan Islam, Jakarta: Bumi Aksara, 2006. 